\title{
Decomposition of Eucalyptus grandis and Acacia mangium leaves and fine roots in tropical conditions did not meet the Home Field Advantage hypothesis
}

\author{
Luciana Ruggiero Bachega ${ }^{a}$, Jean-Pierre Bouillet ${ }^{\mathrm{b}, \mathrm{c}, *}$, Marisa de Cássia Piccolo ${ }^{\mathrm{a}}$, Laurent Saint-André ${ }^{\mathrm{d}}$, \\ Jean-Marc Bouvet ${ }^{\mathrm{e}}$, Yann Nouvellon ${ }^{\mathrm{b}, \mathrm{c}}$, José Leonardo de Moraes Gonçalves ${ }^{\mathrm{b}}$, Agnès Robin ${ }^{\mathrm{c}}$, \\ Jean-Paul Laclau ${ }^{\mathrm{c}, \mathrm{f}}$
}

${ }^{a}$ USP, CENA, 303 Av. Centenario, Piracicaba, SP, CEP 13416-000, Brazil

${ }^{\mathrm{b}}$ USP, ESALQ 11 Av. Padua Dias, Piracicaba, SP, CEP 13418-900, Brazil

${ }^{\mathrm{C}}$ CIRAD, UMR EcoESSols, 2 Place Viala, F34060 Montpellier, France

${ }^{\mathrm{d}}$ INRA, UR BEF, Rue de l'Arboretum, 54280 Champenoux, France

${ }^{\mathrm{e}}$ CIRAD, UMR AGAP, Avenue Agropolis, 34398 Montpellier Cedex 5, France

${ }^{\mathrm{f}}$ UNESP, Ciência Florestal, 1780 Rua José Barbosa de Barros, Botacatu, Brazil

\section{A R T I C L E I N F O}

\section{Article history:}

Received 16 April 2015

Received in revised form 16 September 2015

Accepted 18 September 2015

Available online 29 September 2015

Keywords:
Decomposers
Litter quality
Water soluble compounds
Lignin
$\mathrm{N}$
$\mathrm{P}$

\begin{abstract}
A B S T R A C T
Unlike Eucalyptus monocultures, nitrogen fixing trees are likely to improve the soil nutrient status through the decomposition of N-enriched litter. The Home Field Advantage (HFA) hypothesis states that plants can create conditions that increase the decomposition rates of their own litter. However, there may not be any HFA when most of the decomposers are generalists. A reciprocal transplant decomposition experiment of fine roots and leaves of Acacia mangium and Eucalyptus grandis was undertaken in monocultures of these two species to test the HFA hypothesis using a complete randomized design with three blocks. Three litterbags containing leaf or fine root residues of each species were collected every 3 months from each plot over 12 months for fine roots and 24 months for leaves. The litter mass and $\mathrm{C}, \mathrm{N}$ and $\mathrm{P}$ concentrations were measured at each sampling date. The concentrations of C-compounds were measured 0,12 and 24 months from the start of the experiment. There was no evidence of HFA for either the leaves or the fine roots of either species. The decomposition rates were slower for Acacia litter than for Eucalyptus litter even though initial N concentrations were 1.9-2.9 times higher and P concentrations were 1.5-3.3 times higher in the Acacia residues. N:P ratios were greater than 20-30 for the residues of both species, with the highest values for Acacia. Litter decomposition depended partly on the $\mathrm{C}$ quality of the litter, primarily in terms of water soluble compounds and lignin content. As shown recently in tropical rainforests, these results suggest that the activity of decomposers is limited by energy starvation in tropical planted forests. Decomposer activity may also have been limited by P availability which may not have been directly related to the $P$ concentrations or C:P ratios in the residues.
\end{abstract}

(C) 2015 Elsevier B.V. All rights reserved.

\section{Introduction}

Eucalyptus grandis Hill ex Maid is native to Australia and Acacia mangium Wild is native to Australia and Indonesia. They are widely planted in tropical regions to produce pulp and paper, firewood and charcoal (FAO, 2010; Harwood and Nambiar, 2014; Nambiar and Harwood, 2014). In comparison with Eucalyptus, A. mangium stands have a higher soil $\mathrm{N}$ availability, through the decomposition

\footnotetext{
* Corresponding author at: USP, ESALQ, 11 Av. Padua Dias, Piracicaba, SP, CEP 13418-900, Brazil.

E-mail address: jpbouillet@cirad.fr (J.-P. Bouillet).
}

of N-enriched litter (Voigtlaender et al., 2012; Koutika et al., 2014), as well as a higher diversity of soil fauna and microbial communities (Bini et al., 2013a; Rachid et al., 2013, 2015). A monospecific rotation of $A$. mangium after a certain number of monospecific E. grandis rotations could help to maintain plantation soil fertility in a way that is compatible with commercial forestry practices. In south-east Brazil, the $\mathrm{N}$ soil deficit increases by 150 $250 \mathrm{~kg} \mathrm{ha}^{-1}$ rotation $^{-1}$ in non-N fertilized E. grandis plantations and $\mathrm{N}_{2}$ fixation in pure $A$. mangium plantations varies from 250 to $850 \mathrm{~kg} \mathrm{~N} \mathrm{ha}^{-1}$ rotation $^{-1}$ (Bouillet et al., 2014). As for mixed plantations, replacing one species by another may also have a significant effect on the dynamics of residue and litter decomposition, 
and, therefore, nutrient cycling and carbon sequestration (Xiang and Bauhus, 2007; Forrester et al., 2013; Wu et al., 2014).

Litter decomposition rates vary as a function of litter chemical composition, activity and composition of decomposer communities, and environmental conditions (Hobbie, 2000; Makkonen et al., 2012). The Home Field Advantage (HFA) hypothesis (Gholz et al., 2000) states that plants may create specific conditions that increase the rate of decomposition of their own litter (Vivanco and Austin, 2008; Cizungu et al., 2014). This suggests specialization of the local decomposer community to the characteristics of this litter (Strickland et al., 2009), possibly because the decomposers in the litter environment have specific metabolic capacities (Wickings et al., 2012) and there is transfer from the microbial communities in the phyllosphere (Austin et al., 2014). HFA could also be linked to the attraction of specific soil fauna, to differences in mycorrhizal associations or to differences in the amount and characteristics of rhizodeposition between species (Berg and Smalla, 2009; Cesarz et al., 2013; Austin et al., 2014).

However, several studies have not found supporting evidence for the HFA hypothesis (Chapman and Koch, 2007; Veen et al., 2015) with decomposers showing little preference for litter from different sources (Makkonen et al., 2012). The substrate quality/ matrix quality interaction (SMI) hypothesis based on a continuum from positive interaction to negative interaction between particular types of litter and particular decomposer communities (Freschet et al., 2012b) suggests that some types of litter may decompose more slowly in the home field. For a given species of plant, SMI predicts the existence of a Home Field Advantage when the qualities of the decomposing residues (substrate) and the litter layer (matrix) are more similar under stands of that species than in other environments. If the qualities are less similar in the home field, the decomposition rates should be lower.

Litter nutrient concentrations and stoichiometry are likely to have a significant effect on the abundance and activity of decomposers and, therefore, on decomposition rates (Melillo et al., 1982; Manzoni et al., 2010; Mooshammer et al., 2012). Positive correlations between decomposition rates and $\mathrm{N}$ and $\mathrm{P}$ concentrations were found in a review of 256 studies of the decomposition of plant litter from terrestrial and aquatic environments (Enriquez et al., 1993), and in a meta-analysis of 66 leaf litter decomposition experiments on six continents (Cornwell et al., 2008). Decomposition rates are usually negatively correlated with the C:N ratio (Melillo et al., 1982) and C:P ratio (Enriquez et al., 1993). However, no significant correlation was found between the decomposition rates and C:N ratios for residues of 37 crops (Jensen et al., 2005), and C:P ratios for Fagus sylvatica leaf litter (Mooshammer et al., 2012). Some studies have also reported positive correlations between C:N and decomposition rates (Gödde et al., 1996; Berg and Matzner, 1997; Michel and Matzner, 2002; Berg and McClaugherty, 2003; Craine et al., 2007). Microbial communities respond differently to different litter $\mathrm{N}: \mathrm{P}$ ratio. Fungi become P-limited at higher $\mathrm{N}: \mathrm{P}$ ratios than bacteria (Güsewell and Freeman, 2005). The critical N:P ratio at which litter decomposition shifts from P-limited to N-limited depends on the type of litter (e.g. leaves vs roots) (Vivanco and Austin, 2006) and on the overall nutrient availability (Güsewell and Gessner, 2009).

Carbon compounds have also been identified as drivers of litter decomposition in forest ecosystems (Hättenschwiler et al., 2011). Decomposition rates of leaf litter for six tropical rain forests species were negatively correlated with the initial lignin concentration (Butenschoen et al., 2014). Lignin was also found to reduce the decomposition rates of stems, leaves, fine roots and reproductive organs of 40 forest species (Freschet et al., 2012a). The concentration of condensed tannins was one the three main traits controlling the leaf decomposition rates of 16 woody plant species in a fully reciprocal litter transplant study conducted from the subarctic to the tropics (Makkonen et al., 2012). The two other traits were leaf water saturation capacity and leaf magnesium concentration. The inhibition of litter decomposition by polyphenols was observed for conifer species growing on infertile acid soils in North California (Northup et al., 1995) as well as by condensed tannins for various tree species in French Guyana (Coq et al., 2010). Hättenschwiler et al. (2011) put forward a "litter perspective" with a syndrome of poor litter $C$ quality in tropical rainforests. Slow litter decomposition observed in Amazonian rainforests is partly explained by the low concentrations of easily accessible energyrich $\mathrm{C}$ compounds leading to energy starvation for decomposers (Hättenschwiler and Bracht Jørgensen, 2010).

This study set out to test the HFA hypothesis for litter composed of leaves and fine roots of two tropical tree species with contrasting biochemical properties: A. mangium and E. grandis (BernhardReversat and Schwartz, 1997; Voigtlaender et al., 2012). So far as we are aware, only three studies have tested the HFA hypothesis for fine roots and the results do not show a clear pattern (Gholz et al., 2000; Freschet et al., 2012b; Osanai et al., 2012). Although litter decomposition can be controlled by specific mechanisms in tropical regions (Hättenschwiler and Bracht Jørgensen, 2010; Hättenschwiler et al., 2011), only a few studies have tested the HFA hypothesis in tropical forests (Wang et al., 2013; Veen et al., 2015). Reciprocal root and leaf litter transplant experiments in tropical regions are, therefore, needed to test the generality of the HFA hypothesis. Furthermore, the decomposition of E. grandis and $A$. mangium litter has never been monitored at the same time in the same stands.

Litterbags of E. grandis and A. mangium were placed in monocultures of each species. The litter decomposition was monitored over 12 months for fine roots and 24 months for senesced leaves. This study set out to test the hypotheses that (1) HFA leads to a faster decomposition of the litter of each species in its own monoculture and (2) decomposition of $\mathrm{N}$-rich A. mangium litter is faster than decomposition of N-poor E. grandis litter.

\section{Material and methods}

\subsection{Study site}

The study was carried out at the Itatinga experimental station of São Paulo University $\left(23^{\circ} 02^{\prime} \mathrm{S}, 48^{\circ} 38^{\prime} \mathrm{W}\right)$. Over the two years of the experiment, the mean annual rainfall was $1535 \mathrm{~mm}$ and the mean annual temperature was $20.4^{\circ} \mathrm{C}$. Temperature and rainfall were low during the dry season, from June to September (mean temperature: $16.5^{\circ} \mathrm{C}$; rainfall: $259 \mathrm{~mm}$ ). The experiment was located on the top of a hill (slope $<3 \%$ ) at an elevation of $860 \mathrm{~m}$ asl. The soils were Ferralsols (FAO classification), developed on cretaceous sandstone, Marília formation, Bauru group. The soils had low clay content $(\approx 12 \%)$ and very low CEC, $<2 \mathrm{cmolc} \mathrm{kg}^{-1}$ soil in the $0-15 \mathrm{~cm}$ soil layer (Voigtlaender et al., 2012).

\subsection{Experimental layout}

The study was carried out in a field trial comparing monocultures of A. mangium (A) and E. grandis (E) (Table 1). This trial (complete randomized block design with four blocks) was set up in May 2003 on an area that had previously been managed with Eucalyptus for 60 years (see Bouillet et al., 2013 for a detailed description of the experimental layout). Within each block there were plots with A. mangium monoculture, E. grandis monoculture and mixed plantations of $A$. mangium and E. grandis. Each plot was $30 \mathrm{~m} \times 30 \mathrm{~m}$ with an inner plot $18 \mathrm{~m} \times 18 \mathrm{~m}$ with two buffer rows. The trees were planted at a density of 1111 trees ha $^{-1}$ ( $3 \mathrm{~m} \times 3 \mathrm{~m}$ spacing). Fertilizer ( $\mathrm{P}, \mathrm{K}, \mathrm{Ca}, \mathrm{Mg}$ and micro nutrients) was dug into the soil 
Table 1

Treatments depending on the types of litter, and on the monocultures where the litterbags were placed.

\begin{tabular}{lll}
\hline Litter types & Monocultures & \\
\cline { 2 - 3 } & Acacia (A) & Eucalyptus (E) \\
\hline Acacia leaves (LA) & LAA & LAE \\
Eucalyptus leaves (LE) & LEA & LEE \\
Acacia roots (RA) & RAA & RAE \\
Eucalyptus roots (RE) & REA & REE \\
\hline
\end{tabular}

LAA: Acacia leaves decomposing in Acacia monoculture; LAE: Acacia leaves decomposing in Eucalyptus monoculture; LEA: Eucalyptus leaves decomposing in Acacia monoculture; LEE: Eucalyptus leaves decomposing in Eucalyptus monoculture; RAA: Acacia roots decomposing in Acacia monoculture; RAE: Acacia roots decomposing in Eucalyptus monoculture; REA: Eucalyptus roots decomposing in Acacia monoculture; REE: Eucalyptus roots decomposing in Eucalyptus monoculture;

at the bottom of the trees. No $\mathrm{N}$ fertilizer was applied. The plots in this first six year rotation of the trial were clear cut in May 2009. Only the boles were harvested and the residues were spread uniformly over each plot. A. mangium and E. grandis seedlings were re-planted in the same planting rows in the same plots in November 2009, following the same experimental design and protocol. This litter decomposition study was carried out from October 2010 to October 2012 in $\mathrm{A}$ and $\mathrm{E}$ in three of the blocks. The mean concentrations of $\mathrm{C}, \mathrm{N}$ and $\mathrm{P}$ in the $0-10 \mathrm{~cm}$ soil layer were comparable in the two monocultures with values of $1.1 \%$ in $A$ and $1.2 \%$ in E for total carbon, $0.06 \%$ for both $\mathrm{A}$ and $\mathrm{E}$ for total $\mathrm{N}$, and $5.7 \mu \mathrm{g} \mathrm{g}^{-1}$ in $\mathrm{A}$ and $5.8 \mu \mathrm{g} \mathrm{g}^{-1}$ in $\mathrm{E}$ for available $\mathrm{P}$ (Voigtlaender et al., 2012; Bini et al., 2013a). The $\mathrm{C}: \mathrm{N}$ ratio averaged about 23 in both monocultures, and $\mathrm{pH}\left(\mathrm{CaCl}_{2}\right)$ was 3.9 in $\mathrm{A}$ and 4.0 in E. In October 2010, the mean tree height was $2.4 \mathrm{~m}$ for $A$. mangium and $3.4 \mathrm{~m}$ for $E$. grandis.

\subsection{Plant material and litter decomposition}

Freshly senesced leaves and fine roots (diameter $<2 \mathrm{~mm}$ ) were collected from 6-year-old A. mangium and E. grandis stands adjacent to the experimental blocks. The litter material was air-dried immediately upon collection in the field and stored in dry conditions in the dark until the start of the experiment. Leaves showing signs of damage, fungal or herbivore attack were removed. Petioles were kept as part of the leaves. The litterbags ( $2 \mathrm{~mm}$ rigid nylon mesh) were $20 \mathrm{~cm} \times 30 \mathrm{~cm}$ for Acacia leaves (LA), and $15 \mathrm{~cm} \times 15 \mathrm{~cm}$ for Eucalyptus leaves (LE) and for the fine roots of both species (RA and RE). The litterbags were filled with $10 \mathrm{~g}$ of leaf litter or $7 \mathrm{~g}$ of fine roots. The plant material was inserted in the dimension it was naturally, with leaves ranging from $20-30 \mathrm{~cm}$ and $10-15 \mathrm{~cm}$ in length for LA and LE, respectively. The $2 \mathrm{~mm}$ mesh size provided access for microbes and soil microfauna and mesofauna (Bradford et al., 2002). Ten grams of leaf litter represents about $40 \%$ of the mean annual leaf litterfall on a ground area of $20 \mathrm{~cm} \times 30 \mathrm{~cm}$ for A and $100 \%$ of the litterfall on $15 \mathrm{~cm} \times 15 \mathrm{~cm}$ for E (Nouvellon et al., 2012). Seven grams of root litter represented about $60 \%$ of the mean annual fine root production in a $15 \mathrm{~cm} \times 15 \mathrm{~cm}$ ground area for A and $45 \%$ for $\mathrm{E}$ (Nouvellon et al., 2012). The litterbags of each species (i.e. A. mangium and E. grandis) were placed in each monoculture (i.e. A and E) in three different blocks, creating a reciprocal litter transplant experiment with four treatments for each type of residue (leaf or fine root) (Table 1).

In each plot ( 1 monoculture in 1 block), 8 litterbags of leaves from each species were placed on the forest floor close to 3 different trees of average size (24 litterbags per plot for the leaves from each species). These litterbags were secured at their corners with stainless steel nails. Four litterbags of fine roots from each species were buried at a depth of $5 \mathrm{~cm}$ in the soil, about $10 \mathrm{~cm}$ from the litterbags with the leaves from the same species. The litterbags were distributed to cover the spatial variability relative to the trees. The lower edges of plastic boards $20 \mathrm{~cm}$ high were sunk in the soil down to a depth of $15 \mathrm{~cm}$ between the litterbags with litter from different species to prevent cross infection by fungus hyphae. In total, there were 288 litterbags with leaves ( 2 leaf species $\times 8$ positions relative to the trees $\times 3$ trees $\times 2$ monocultures $\times 3$ blocks) and 144 litterbags with fine roots (4 positions instead of 8 ). The litterbags with fine roots were collected 92, 181, 275, 367 days after installation, and litterbags with leaves were collected $92,181,275,367,464,549,640,725$ days after installation. Fine root decomposition was measured over a period of 12 months only, as preliminary results showed rapid root decay and a high level of soil contamination in the root litter after 1 year.

\subsection{Chemical and C-compound analyses}

In the laboratory, leaves remaining in the litter were carefully brushed and fine roots were gently rinsed in tap water and cleaned by hand to remove soil particles and exogenous material. The leaves and fine roots were dried for 4 and 7 days, respectively. The drying temperature was $65^{\circ} \mathrm{C}$ for chemical analyses and $40{ }^{\circ} \mathrm{C}$ for C-compound analyses (Van Soest, 1964). The initial dry matter and $\mathrm{C}, \mathrm{N}$ and $\mathrm{P}$ concentrations were determined for 9 samples of each type of litter. The ash content was determined by heating sub-samples at a $500{ }^{\circ} \mathrm{C}$ in an oven for $4 \mathrm{~h}$ and the ash content was used as a correction to determine the ash-free dry mass and chemical properties. $\mathrm{C}$ and $\mathrm{N}$ were determined by TruSpec Micro CHN elemental analyzer (LECO, St. Joseph, Michigan, USA). Phosphorus was determined after nitric acid digestion by UV spectrophotometer (Hitachi, U2001, Tokyo, Japan) using the molybdovanadate method. C-compound analyses were performed at the start of the experiment on five samples of leaves and fine roots from each species. One composite sample of the roots and of the leaves of each species, from the monocultures of each tree species in each block, was analyzed at 367 days. One composite sample of the leaves of each species, from the monocultures of each tree species in each block was analyzed at 725 days. For a given species and type of residue, the variability between monocultures of the different tree species (2) and between the blocks (3) was low. The results were, therefore, grouped by type of residue for each species (giving 6 replicates for each of LA, LE, RA, and RE at 367 days, and 6 replicates for LA and LE at 725 days). The water soluble compound (WSC) concentration was determined by colorimetry after extraction in water. The concentrations of cellulose, hemicellulose and acid unhydrolyzable residue (AUR, as a measure of lignin, Van Soest, 1964), were determined by successive extractions with acid detergent. After extraction in acetone solution, the total phenols were assayed using the Folin-Ciocalter method, total tannins were assayed using polyvinylpyrrolidone (PVPP) and condensed tannins were assayed using butanol-HCl (Makkar et al., 1993).

\subsection{Data analyses}

The litter mass was expressed as a percentage of the initial oven-dried litter weight. For each type of residue, the variances of the remaining mass, $\mathrm{N}, \mathrm{P}$ and the $\mathrm{C}: \mathrm{N}, \mathrm{C}: \mathrm{P}$ and $\mathrm{N}: \mathrm{P}$ ratios were analyzed for each collection date using a linear model (model 1). A linear mixed model (model 2) was used to test the effects on the remaining mass of the monocultures, the residue species, the block and the interaction between monocultures and residue species as fixed effects, as well as the collection dates and the interaction between collection dates and monocultures, and between collection dates and residue species as random effects. Residuals were modeled by a first order autoregressive correlation model 
to account for the correlations between collection dates. The best model using Akaike Information Criterion (AIC) was selected. For a given type of residue, the existence of HFA was observed if the interaction between monocultures and residue species was significant and if the remaining mass for a given residue species was significantly lower in the monoculture of that species than in the monoculture of the other species. The Generalized Linear Model (GLM) procedure of SAS 6.11 was used (SAS Institute, Cary, NC, USA) for the fixed effects models. The ASReml statistical package (Gilmour et al., 2005) was used for the linear mixed models. The homogeneity of variances was tested by Levene's test, and the normal distribution of residuals was tested with the Shapiro-Wilks test. The values of the remaining mass and the residue quality variables (e.g. lignin, cellulose) were Arsin(sqrt)-transformed to stabilize variances. Bonferroni's test was used for multiple comparisons for fixed effects models. Wald's test was used for mixed effects models. The significance level was 0.05 .

\section{Results}

\subsection{Decomposition}

Leaf decomposition was not significantly affected by the tree species in the monoculture, regardless of the leaf species and the sampling date (model 1), except that the decomposition rate of LEE was greater than LEA at 464 days (Fig. 1a). The remaining mass was significantly lower for Eucalyptus leaves than Acacia leaves at the first two collection dates. At 181 days, the remaining mass was on average $63 \%$ of the initial dry matter for Eucalyptus leaves and $88 \%$ for Acacia leaves. The remaining mass was still lower thereafter for Eucalyptus leaves than for Acacia leaves falling to $38 \%$ and $41 \%$ of the initial dry matter at 725 days, respectively. Consistently, the overall pattern of decomposition of Eucalyptus leaves and Acacia leaves was significantly different over the study period (model 2) $(F=30.39 ; P<0.001)$. The Eucalyptus leaves had a higher initial decomposition rate while the Acacia leaves decomposed more steadily over the two years. The effect of the monoculture on mass loss and the interaction between monoculture and residue species were not significant.

As for leaves, fine root decomposition was not significantly affected by the species in the monoculture, regardless of the root species and sampling date (model 1), except that the mass loss of RAA was less than RAE at 181 days (Fig. 1b). Fine root decomposition was not significantly different between the two root species, except at 275 days when the remaining mass was significantly lower for REA and REE than for RAA. However, Eucalyptus fine roots decomposed slightly faster than Acacia fine roots with, on average, a remaining mass at 367 days of $29 \%$ and $36 \%$ for Eucalyptus and Acacia fine roots, respectively. The root species and monoculture did not significantly affect the fine root decomposition (model 2). There was a significant interaction between the monoculture and the root species $(F=5.32 ; p=0.025)$ shown by a global higher remaining mass for RAA than for the other treatments.

\subsection{Nutrient concentrations and nutrient stoichiometry}

$\mathrm{N}$ concentrations were significantly higher within Acacia residues than Eucalyptus residues, and increased with time in all cases
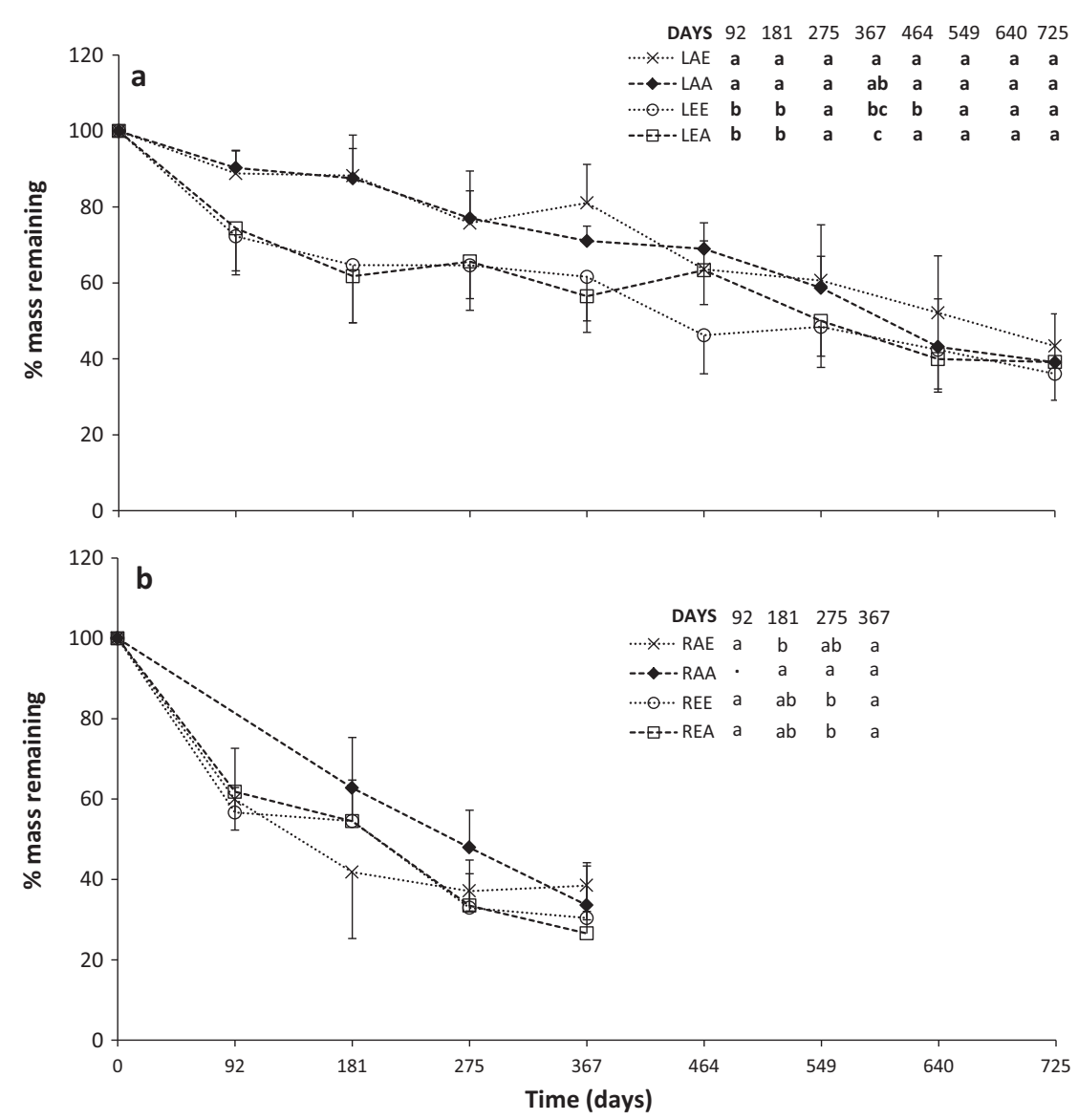

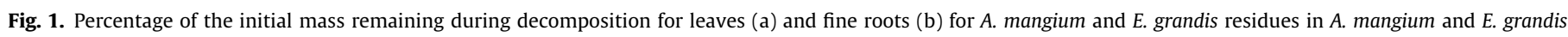

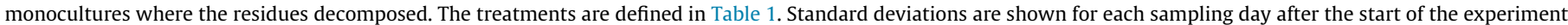

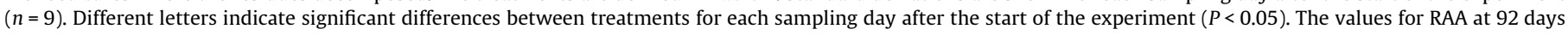
are missing. 
(Fig. 2a and b). From the start of the experiment to the end (at 725 days) the $\mathrm{N}$ concentration increased from $1.6 \%$ to $2.8 \%$ in Acacia leaves and increased from $0.8 \%$ to $1.8 \%$ in Eucalyptus leaves. From the start of the experiment to 367 days (the last sampling date for root residues), the $\mathrm{N}$ concentration increased from $2.3 \%$ to $3.3 \%$ in Acacia fine roots, and from $0.8 \%$ to $2.0 \%$ in Eucalyptus fine roots.

The initial P concentration was higher in Acacia residues than in Eucalyptus residues (Fig. 2c and d). From 92 days onwards, the $\mathrm{P}$ concentration in Acacia leaves and Eucalyptus leaves was similar and increased over the 2 years of decomposition. There was a marked decrease in the P concentration at 92 days in Acacia roots. However, the P concentration was again higher in Acacia roots than in Eucalyptus roots at 275 and 367 days.

While the initial C:N and C:P ratios were significantly higher for Eucalyptus residues than Acacia residues, over the study period only the differences in the C:N ratio were significant (Fig. 3a-d). The C:N ratios of Eucalyptus residues halved over the study period, from 71 to 33 for Eucalyptus leaves, and from 62 to 29 for Eucalyptus fine roots. The C:N ratio for Acacia residues decreased much less over the study period, from 34 to 22 for Acacia leaves, and from 22 to 18 for Acacia roots. From 92 days onwards, there was no consistent pattern for the $\mathrm{C}: \mathrm{P}$ ratios.

The N:P ratios tended to be higher in Acacia leaves than in Eucalyptus leaves with significant differences at the start of the experiment and at most sampling dates (Fig. 3e). The initial N:P ratios in Acacia fine roots (21) and Eucalyptus fine roots (22) were not significantly different. The $\mathrm{N}: \mathrm{P}$ ratios at 92 days in Acacia fine roots were significantly higher reaching a peak value of 63 . The highest $N: P$ ratios were for RAA (Fig. 3f). In contrast, the N:P ratios in Eucalyptus fine roots stayed between 20 and 37 over the study period.

\subsection{Carbon compounds}

The initial carbon compound concentrations in the Acacia residues and Eucalyptus residues were markedly different. Concentrations of water soluble compounds (WSC), total tannins and total phenolics were significantly lower in Acacia leaves than in Eucalyptus leaves (Fig. 4) while Eucalyptus leaves had significantly lower concentrations of AUR and condensed tannins. The concentrations of WSC, total and condensed tannins, and total phenolics decreased markedly in the residues of both species over the first year of decomposition. The concentration of cellulose decreased steadily over the study period, from $22 \%$ to $5 \%$ at 724 days in Acacia leaves, and from $22 \%$ to $4 \%$ at 724 days in Eucalyptus leaves. The concentration of hemicellulose also decreased in Acacia leaves, from 14\% to $8 \%$ at 724 days while the concentration of hemicellulose in Eucalyptus leaves remained at about $8-9 \%$ over the study period. There was no marked change in AUR concentration over the study period with a small decrease (from $37 \%$ to $33 \%$ ) in Acacia leaves and a slight increase (from 20\% to 25\%) in Eucalyptus leaves.

The concentrations of WSC, cellulose, total and condensed tannins and total phenolics were significantly lower and the concentration of hemicellulose was significantly higher in Acacia fine roots than in Eucalyptus fine roots (Fig. 5). The concentrations of AUR in Acacia fine roots and Eucalyptus fine roots were similar. As shown for leaves, the concentrations of WSC, total and condensed tannins, and total phenolics were very low after one year of decomposition. From the start of the experiment to 367 days, the concentration of cellulose decreased from 31\% to 13\% in Acacia fine roots and from $39 \%$ to $16 \%$ in Eucalyptus fine roots. The concentration of hemicellulose decreased from $11 \%$ to $8 \%$ in Acacia fine roots and from 9\% to 7\% in Eucalyptus fine roots. The concentration
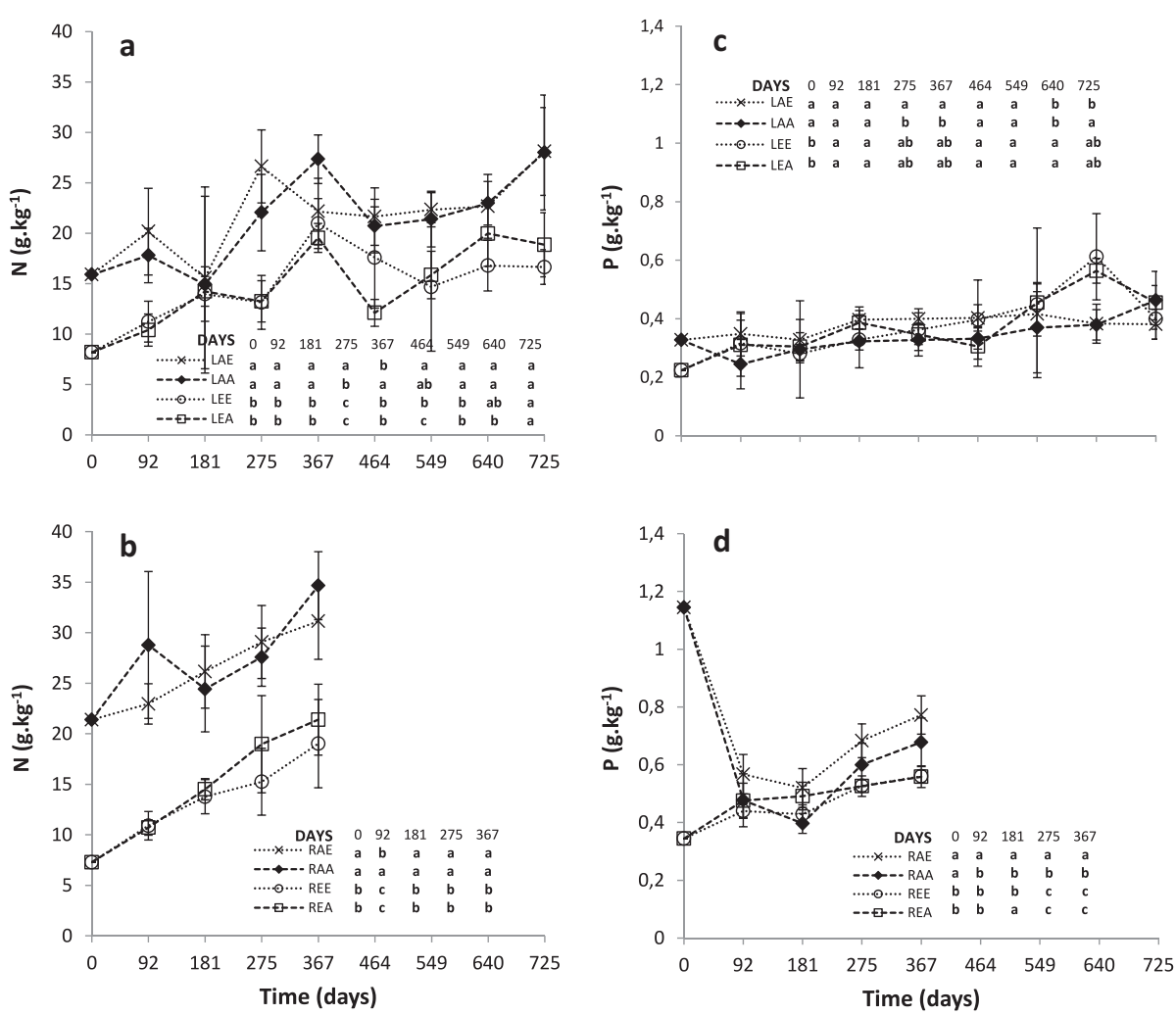

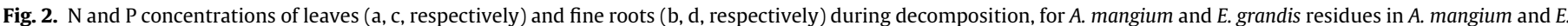

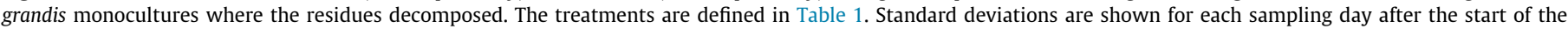
experiment $(n=9)$. Different letters indicate significant differences between treatments for each sampling day after the start of the experiment $(P<0.05)$. 

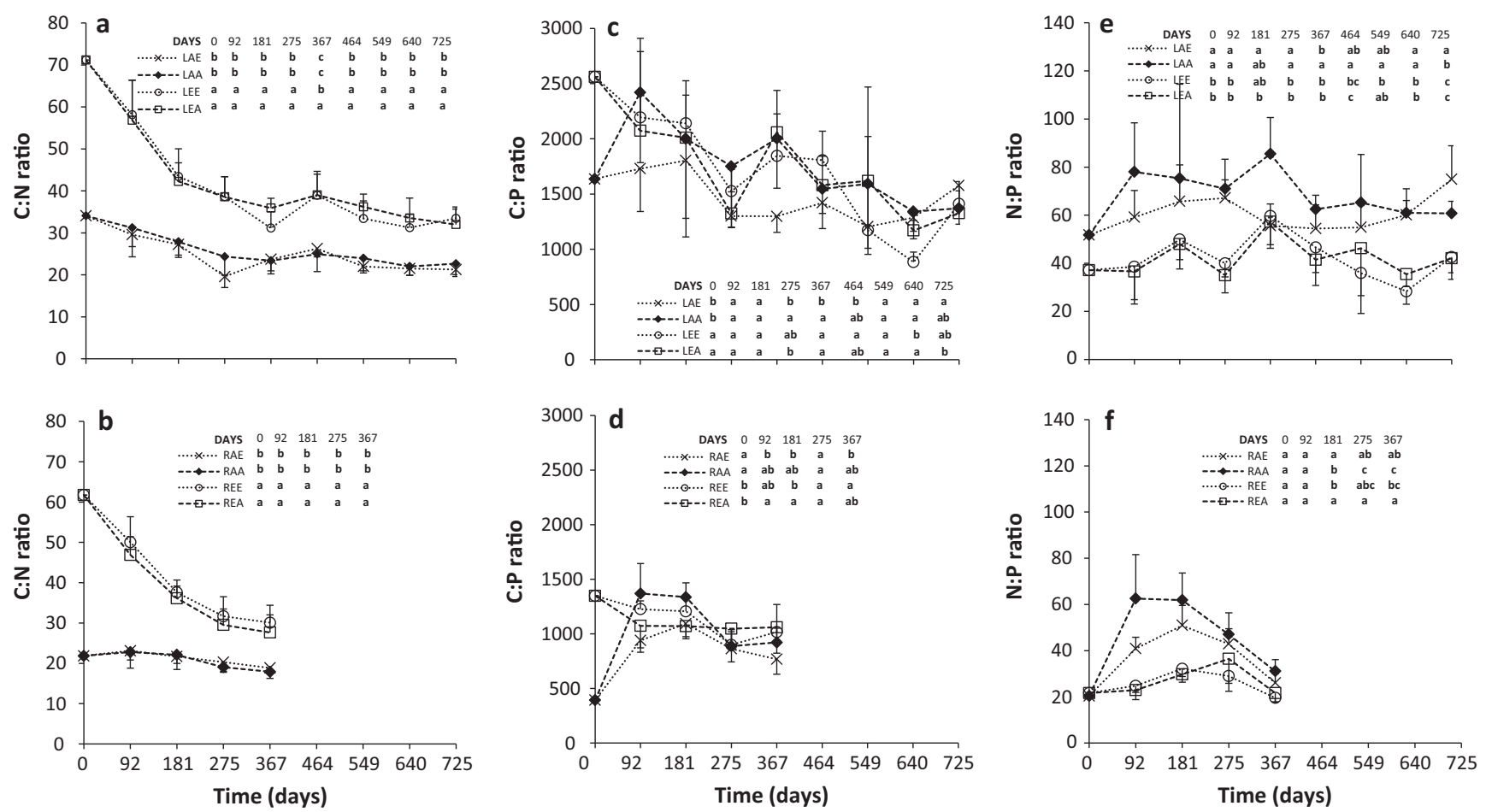

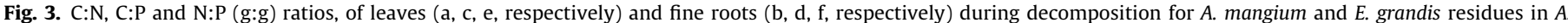

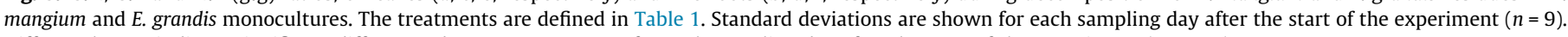
Different letters indicate significant differences between treatments for each sampling day after the start of the experiment $(P<0.05)$.

of AUR at 367 days was 24\% in Acacia fine roots and 20\% in Eucalyptus fine roots.

\section{Discussion}

\subsection{Effect of the monoculture on litter decomposition}

This study did not confirm the first hypothesis as no HFA was observed. The residue decomposition was not affected by the tree species in the monoculture for either roots or leaves of either species. This result was obtained despite an experimental design that was well suited to demonstrating HFA, as the litter had very different characteristics (Ayres et al., 2009) and the ecosystems were dominated by single plant species (Vivanco and Austin, 2008). However, it cannot be discounted that Acacia might not have demonstrated HFA because the time since the start of the first Acacia rotation (in May 2003) was not long enough to allow the decomposers to become specialized for Acacia residues, or because the study was conducted in an area to which the species was not native. This is unlikely to be the case for Eucalyptus since the experimental site had been cultivated with eucalypts for 60 years before the trial was set up. Previous studies in the same experimental trial showed that replacing Eucalyptus by Acacia trees rapidly led to drastic changes in $\mathrm{N}$ cycling and microbial communities and their activity, suggesting that, even for the Acacia plantations, there should have been sufficient time for the decomposer community to adapt to Acacia residues. Soil $\mathrm{N}$ mineralization was twice as high in Acacia monoculture (A) than in Eucalyptus monoculture (E) during the last two years of the first Acacia rotation (Voigtlaender et al., 2012). The microbial biomass, microbial C:N ratio, microbial respiration, soil bacteria abundance, and soil dehydrogenase activities were significantly higher in A than in E 14 months after the start of the second Acacia rotation (Bini et al., 2013a,b). In contrast, soil fungi abundance was lower in A than in E (Bini et al., 2013b). The soil bacterial and fungal communities had distinctly different structures in A and E (data not shown) as found in another area of Brazil, two years after afforestation (Rachid et al., 2013, 2015). Where HFA has been observed, it appears rapidly (1-2 years) in forest ecosystems (Ayres et al., 2009), which suggests that the length of our study was sufficient. Contrary to other studies (e.g. Vivanco and Austin, 2008), the lack of HFA showed that the direct control of litter properties on decomposition was stronger than the effects of the soil biota and environment. These results seem consistent with recent studies at a global scale showing that litter decomposers have a high metabolic flexibility (Makkonen et al., 2012).

HFA could be considered as a special case of the substrate quality/matrix quality interaction (SMI) hypothesis (Freschet et al., 2012b) for leaf litter. The quality of the decomposing residue (substrate) and the litter layer (matrix) is basically represented by the lignin content and an integrative indicator of carbon/nutrient economics (including the $\mathrm{N}$ concentration and the $\mathrm{C}: \mathrm{N}$ ratio). This is confirmed by the more complete decomposition of Fagus sylvatica leaves at sites where the $\mathrm{C}: \mathrm{N}$ ratios of the humus were closer to that of the initial litter (d'Annunzio et al., 2008). The results for the decomposition of Eucalyptus leaves did not support the SMI hypothesis. If the SMI hypothesis was valid, HFA should have been observed for Eucalyptus leaves as their quality was closer to that of the soil litter in $\mathrm{E}$ than in $\mathrm{A}$. The initial $\mathrm{N}$ and $\mathrm{C}: \mathrm{N}$ ratios were $1.6 \%$ and 71 in the Eucalyptus leaves, while the $\mathrm{N}$ and $\mathrm{C}: \mathrm{N}$ ratios in the litter layer were $1.3 \%$ and 33 in E, and $2.6 \%$ and 21 in A (Bini et al., 2013a). Because the lignin concentration in the Eucalyptus leaves did not change much during decomposition, the lignin concentration in the Eucalyptus leaves was also likely to be closer to that of the soil litter in E than in A.

\subsection{Litter decay and litter traits}

Contrary to the second hypothesis, the early decomposition was markedly slower for Acacia leaves than for Eucalyptus leaves, 

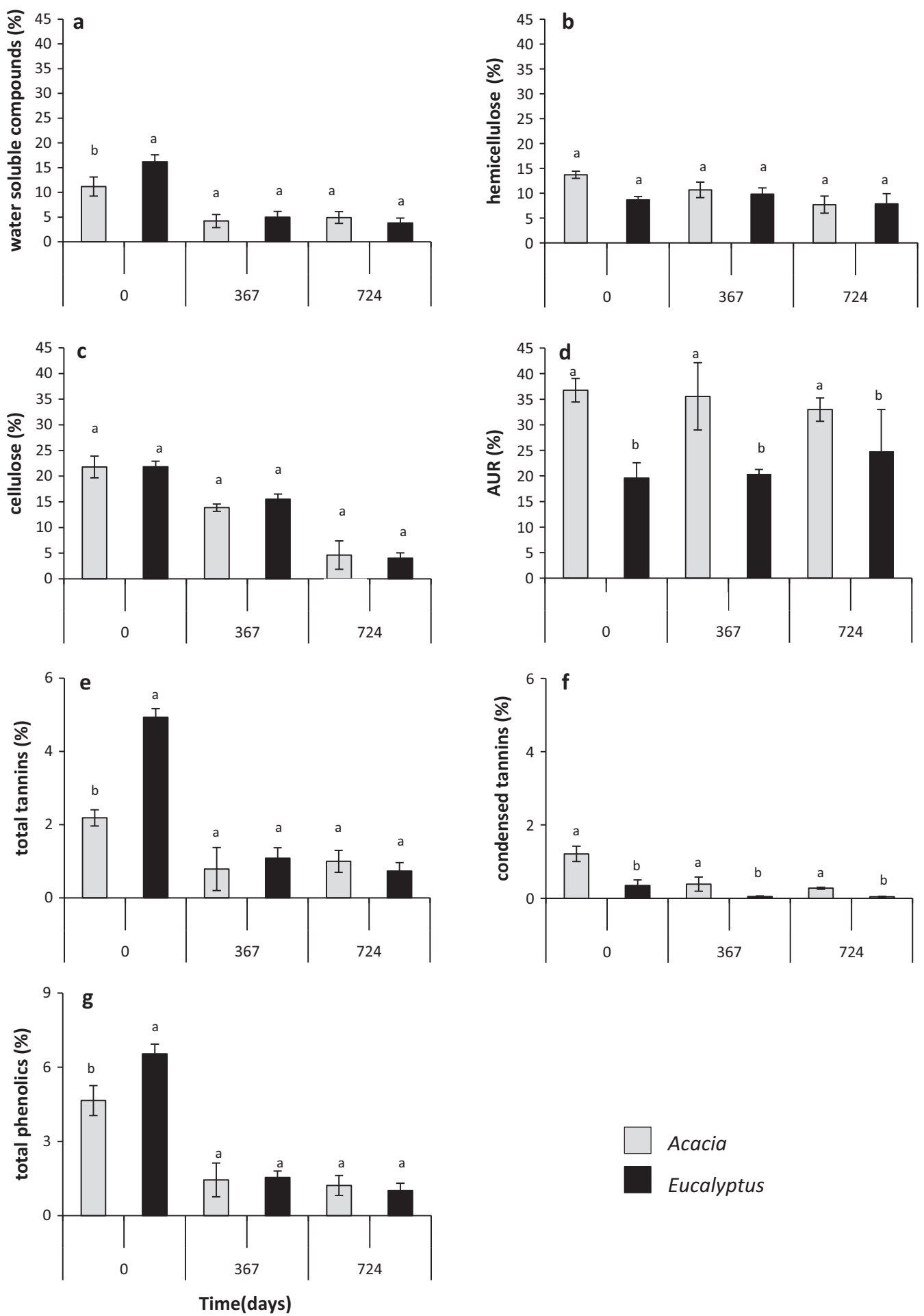

Acacia

Eucalyptus

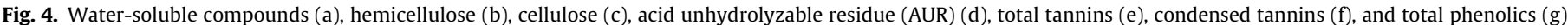

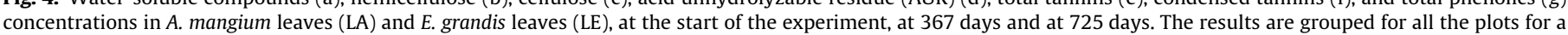

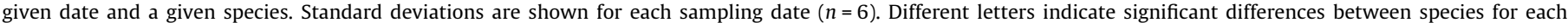
sampling date $(P<0.05)$.

irrespective of the tree species in the monoculture, although the initial concentrations of $\mathrm{N}$ and $\mathrm{P}$ in Acacia leaves were 1.9 and 1.5 times higher than in Eucalyptus leaves, respectively. Acacia fine roots did not decompose faster than Eucalyptus fine roots despite initial $\mathrm{N}$ and $\mathrm{P}$ concentrations that were 2.9 and 3.3 times higher, respectively. Lower values of $\mathrm{C}: \mathrm{N}$ and $\mathrm{C}: \mathrm{P}$ ratios were not associated with higher litter decomposition rates. Acacia leaves and fine roots did not decompose more rapidly than Eucalyptus leaves and fine roots despite $\mathrm{C}: \mathrm{N}$ values $2-3$ times lower at the start of the experiment and still 50\% lower at the end. Likewise, the initial C:P ratio in Acacia leaves was 35\% lower than in Eucalyptus leaves and $70 \%$ lower in Acacia fine roots than in Eucalyptus fine roots. These results differ from the positive correlations between litter decomposition rates and $\mathrm{N}$ and $\mathrm{P}$ concentrations (and therefore 

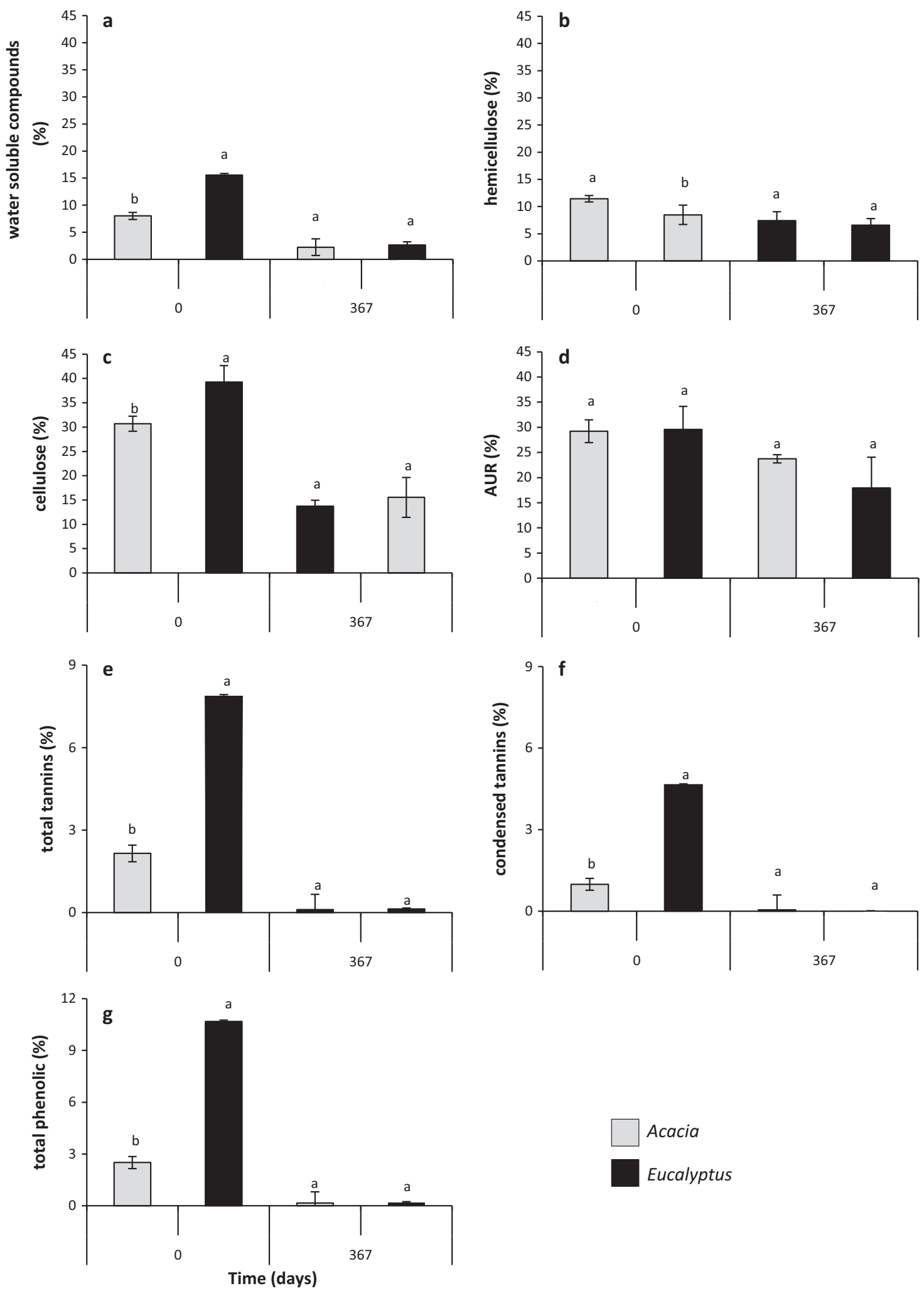

Acacia

Eucalyptus

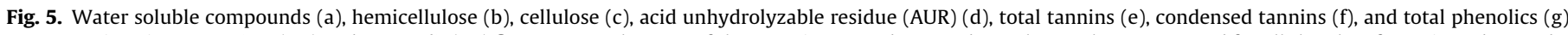

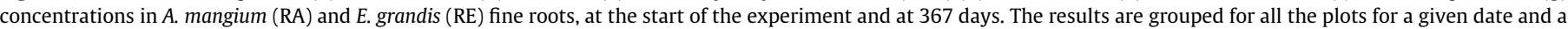

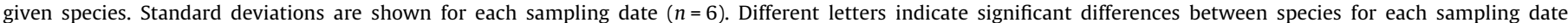
$(P<0.05)$.

negative correlations between the decomposition rates and the C:N and C:P ratios) observed across various types of ecosystem (Silver and Miya, 2001; Hessen et al., 2004; Cornwell et al., 2008), at least in the early stages of decomposition (Hobbie et al., 2012). However, the decomposition rates of the leaves of four species of Amazonian trees were not correlated with either the average leaf litter 
$\mathrm{C}: \mathrm{N}$ ratio or the concentrations of $\mathrm{N}$ and $\mathrm{P}$ in various treatments (Hättenschwiler and Bracht Jørgensen, 2010). Similarly, correlations between the decomposition rates of fine roots of four species of temperate forest trees and $\mathrm{N}, \mathrm{P}, \mathrm{C}: \mathrm{N}$ or $\mathrm{C}: \mathrm{P}$ were not significant (Sun et al., 2013). Positive correlations between litter decomposition and C: $\mathrm{N}$ ratio could be observed in the later stages of litter decomposition (Berg and Matzner, 1997).

Leaf and fine root decomposition patterns of the two species in this study were consistent with the first two phases of the decay model proposed by Berg (2000), with an early decomposition stage, characterized by the rapid loss of non-structural carbohydrates and low-molecular-weight phenolics (Hättenschwiler and Bracht Jørgensen, 2010; Hättenschwiler et al., 2011) followed by a second stage when decomposition is regulated by lignin degradation. This pattern was observed in other tropical areas during the decomposition of Eucalyptus fine roots (Mello et al., 2007) and leaves of both A. mangium and Eucalyptus trees (Corbeels et al., 2003; Castellanos-Barliza and Leon Pelaez, 2011).

No clear relationship was found between initial condensed tannins concentrations and litter decomposition patterns. The initial condensed tannins concentration in Acacia leaves was 4 times higher than in Eucalyptus leaves and the remaining mass at the end of the study period was also higher in Acacia leaves. This was consistent with the inhibiting effect of condensed tannins on litter decomposition through a reduction in soil enzyme activity (Joanisse et al., 2007) or in soil macrofauna activity (Coq et al., 2010). However, the decomposition rates were higher for Eucalyptus fine roots than Acacia fine roots, even though Eucalyptus fine roots had condensed tannins concentrations that were 5 times greater than Acacia fine roots. These conflicting results might be partly explained by the partial exclusion of soil macrofauna from the $2 \mathrm{~mm}$ mesh litterbags. However, the very low concentration of condensed tannins after one year of decomposition for both Acacia and Eucalyptus residues (Figs. 4 and 5) suggests that condensed tannins only had a minor inhibiting effect on decomposition.

While a negative correlation between lignin: $\mathrm{N}$ ratios and residue decomposition rates is commonly found in the literature (e.g. Melillo et al., 1982), decomposition rates were lower for Acacia residues than for Eucalyptus residues despite the Acacia residues having lower initial lignin: $N$ ratios. The lignin: $N$ ratio was 14 and 13 in Acacia leaves and fine roots, respectively, while it was 27 and 38 in Eucalyptus leaves and fine roots. The lignin: $N$ ratios and leaf litter decomposition rates were not found to be correlated in Eucalyptus globulus plantations (Ribeiro et al., 2002). Likewise, lignin: $\mathrm{N}$ ratios and fine root decomposition rates of tree species were not significantly correlated at a global scale (Silver and Miya, 2001).

The higher decomposition rates for fine roots than for leaves of both species in our study were contrary to the findings for woody and herbaceous species across the world in a meta-analysis (Freschet et al., 2013). However, in that meta-analysis, the mean decomposition rates for forest species were only slightly lower for fine roots than for leaves, and some individual studies showed higher decomposition rates for fine roots in the early stages (e.g. Hobbie et al., 2010). Higher decomposition rates for fine roots than for leaves were also observed in Hawaii (Ostertag and Hobbie, 1999) for Metrosideros polymorpha, which belongs to the same family, Myrtacae, as the Eucalyptus genus.

\subsection{Factors related to litter composition that may control decomposer} activity

The higher initial WSC concentrations and litter decomposition rates for Eucalyptus residues than for Acacia residues suggest that decomposers were partly controlled by the availability of readily leached and easily accessible energy-rich C compounds. These findings are consistent with the primarily energy limitation of forest litter decomposers in tropical conditions found in Amazonian rain forest (Hättenschwiler et al., 2011). The hypothesis of energy limitation of decomposers could also be supported by the lower decomposition rates associated with the lower cellulose concentrations for leaves than for roots, and the slower decomposition of Acacia residues associated with higher concentrations of lignin, a compound with a net decomposition energy cost (Moorhead et al., 2013). Consistently, Acacia leaves always had lower decomposition rates and higher LCI (= lignin/(lignin + cellulose), Melillo et al., 1989) than Eucalyptus leaves over the study period. LCI varied from 0.63 at the start to 0.88 at the end of the experiment in Acacia leaves, and from 0.47 to 0.86 for Eucalyptus leaves. The trend of lower decomposition rates in Acacia fine roots might also be associated with their higher LCI which varied from 0.49 to 0.64 in Acacia fine roots and from 0.43 to 0.55 in Eucalyptus fine roots over the study period.

Lower decomposer activities for Acacia leaves than for Eucalyptus leaves could be associated with the higher lignin and $\mathrm{N}$ concentrations and lower C: $\mathrm{N}$ ratio in Acacia leaves than in Eucalyptus leaves. Microbial N limitation has been shown to trigger selective lignin degradation during decomposition of Picea rubens forest floor (Gödde et al., 1996). Decreasing C:N ratios has been shown to decrease soil respiration and stabilize soil organic matter in the Oa horizon in Picea abies stands (Michel and Matzner, 2002).

Phosphorus limitation of microbial decomposers which is usually more detrimental in the early stage of decomposition (Güsewell and Freeman, 2005) was suggested by N:P ratios $>20$ 30 for the residues from the two species (Güsewell and Freeman, 2005; Güsewell and Verhoeven, 2006). This limitation was likely more marked for Acacia residues with $\mathrm{N}: \mathrm{P}$ ratio $>40$. The initial rise in the N:P ratio in the P-rich Acacia fine roots might result from a rapid loss of solubilized inorganic P (Uselman et al., 2012). The lack of any relationship between litter decomposition rates and the initial values of $P$ concentration and the $C: P$ ratio suggests that these parameters are not sufficient to characterize the availability of endogenous $\mathrm{P}$ for decomposers over the period of the experiment.

\section{Conclusions}

HFA did not occur for either leaves or fine roots of the two species in this study. Decomposition rates were slower for Acacia residues than for Eucalyptus residues despite initial higher $\mathrm{N}$ and $\mathrm{P}$ concentrations in the Acacia residues. The decomposition rates depended on the carbon quality of the litter, primarily in terms of water soluble compounds and lignin, and on the P availability. The complexity of the relationships between litter quality and decomposer activity should be studied to improve our understanding of litter decomposition in forest ecosystems (Freschet et al., 2012b). This issue is particularly relevant for studies dealing with the introduction of legume tree species into eucalypt monocultures (Binkley et al., 2001; Forrester et al., 2006; Forrester, 2014) or inter-cropping (Corbeels et al., 2003). The dynamics of carbon and nutrient release throughout the decomposition of litter and harvest residues strongly influence the productivity of eucalypt plantations (Laclau et al., 2010; Mendham et al., 2014) and these results suggest that the tree species re-planted after clear-cutting has little effect on the decomposition of slash. Other in situ studies are needed to assess the functional diversity and the temporal dynamics of decomposers across forest plant species, soils and climates (Cleveland et al., 2014). Detailed characterization of the litter quality is required, covering easily degradable compounds providing energy in the first phases of decomposition through to low quality $\mathrm{C}$ and decomposer-inhibiting compounds (Coq et al., 2010). It is also important that litter decomposition models should 
take account of the interactions between litter quality and decomposer activities explicitly (Ågren et al., 2001; Kaiser et al., 2014).

\section{Acknowledgments}

Financial support was received from CNPq - Brazil, FAPESP Thematic Project - Brazil (2010/16623-9), Intens\&fix Project - France (ANR-2010-STRA-004-03) and ATP Neucapalm - France (CIRAD). We should also like to thank Rildo Moreira e Moreira (USPEsalq), Eder Araujo da Silva (www.floragroapoio.com .br), the staff at the Itatinga experimental station, Cena laboratories and UMR Eco\&Sols for their technical support.

\section{References}

Ågren, G., Bossata, E., Magill, A., 2001. Combining theory and experiment to understand effects of inorganic nitrogen on litter decomposition. Oecologia 128, 94-98.

Austin, A.T., Vivanco, L., Gonzalez-Arzac, A., Perez, L.I., 2014. There's no place like home? An exploration of the mechanisms behind plant litter-decomposer affinity in terrestrial ecosystems. New Phytol. 204, 307-314.

Ayres, E., Steltzer, H., Simmons, B.L., Simpson, R.T., Steinweg, J.M., Wallenstein, M.D., Mellor, N., Parton, W.J., Moore, J.C., Wall, D.H., 2009. Home-field advantage accelerates leaf litter decomposition in forests. Soil Biol. Biochem. 41, 606-610.

Berg, B., 2000. Decomposition and organic matter turnover in northern forest soils. For. Ecol. Manage. 133, 13-22.

Berg, B., Matzner, E., 1997. Effect of N deposition on decomposition of plant litter and soil organic matter in forest systems. Environ. Rev. 5, 1-25.

Berg, B., McClaugherty, C., 2003. Plant Litter. Decomposition. Humus Formation. Carbon Sequestration. Springer Verlag, Heidelberg, Berlin.

Berg, G., Smalla, K., 2009. Plant species and soil type cooperatively shape the structure and function of microbial communities in the rhizosphere. FEMS Microbiol. Ecol. 68, 1-13.

Bernhard-Reversat, F., Schwartz, D., 1997. Change in lignin content during litter decomposition in tropical forest soils (Congo): comparison of exotic plantations and native stands. C.R. Acad. Sci. - Sci. Terre Planèt. 325, 427-432.

Bini, D., dos Santos, C., Bouillet, J.P., Gonçalves, J.L.M., Cardoso, E.J.B.N., 2013a. Eucalyptus grandis and Acacia mangium in monoculture and intercropped plantations: evolution of soil and litter microbial and chemical attributes during early stages of plant development. Appl. Soil Ecol. 63, 57-66.

Bini, D., Figueiredo, A.F., da Silva, M.C.P., Vasconcellos, R.L.F., Cardoso, E.J.B.N., 2013b. Microbial biomass and activity in litter during the initial development of pure and mixed plantations of Eucalyptus grandis and Acacia mangium. Rev. Bras. Ciênç. Sol. 37, 76-85.

Binkley, D., Giardina, C., Bashkin, M.A., 2001. Soil phosphorus pools and supply under the influence of Eucalyptus saligna and nitrogen-Fixing Albizia facaltaria. For. Ecol. Manage. 128, 241-247.

Bouillet, J.P., Laclau, J.P., Gonçalves, J.L.M., Voigtlaender, M., Gava, J.L., Leite, F.P., Hakamada, R., Mareschal, L., Mabiala, A., Tardy, F., Levillain, J., Deleporte, P., Epron, D., Nouvellon, Y., 2013. Eucalyptus and Acacia tree growth over entire rotation in single- and mixed-species plantations across five sites in Brazil and Congo. For. Ecol. Manage. 301, 89-101.

Bouillet, J.P., Voigtlaender, M., Laclau, J.P., Gonçalves, J.L.M., Gava, J.L., Leite, F.P., Hakamada, R.E., Mareschal, L., Mabiala, A., Nouvellon, Y., 2014. Efeito da associação de leguminosas no ciclo de nitrogênio nas plantações de eucaliptos. Série Técnica IPEF 18, 26-36.

Bradford, M.A., Tordoff, G.M., Eggers, T., Hefin Jones, T., Newington, J.E., 2002. Microbiota, fauna, and mesh size interactions in litter decomposition. Oikos 99, 317-323.

Butenschoen, O., Krashevska, V., Maraun, M., Marian, F., Sandmann, D., Scheu, S. 2014. Litter mixture effects on decomposition in tropical montane rainforests vary strongly with time and turn negative at later stages of decay. Soil Biol. Biochem. 77, 121-128.

Castellanos-Barliza, J., Leon Pelaez, J.D., 2011. Litter decomposition and nutrient release in Acacia mangium plantations established on degraded soils of Colombia. Rev. Biol. Trop. 59, 113-128.

Cesarz, S., Fender, A.C., Beyer, F., Valtanen, K., Pfeiffer, B., Gansert, D., Hertel, D., Polle, A., Daniel, R., Leuschner, C., Scheu, S., 2013. Roots from beech (Fagus sylvatica L.) and ash (Fraxinus excelsior L.) differentially affect soil microorganisms and carbon dynamics. Soil Biol. Biochem. 61, 23-32.

Chapman, S.K., Koch, G.W., 2007. What type of diversity yields synergy during mixed litter decomposition in a natural forest ecosystem? Plant Soil 299, 153162 .

Cizungu, L., Staelens, J., Huygens, D., Walangululu, J., Muhindo, D., Van Cleemput, O., Boeckx, P., 2014. Litterfall and leaf litter decomposition in a central African tropical mountain forest and Eucalyptus plantation. For. Ecol. Manage. 326, 109116.

Cleveland, C.C., Reed, S.C., Keller, A.B., Nemergut, D.R., O’Neill, S.P., Ostertag, R., Vitousek, P.M., 2014. Litter quality versus soil microbial community controls over decomposition: a quantitative analysis. Plant Soil 174, 283-294.
Coq, S., Souquet, J.M., Meudec, E., Cheynier, V., Hättenschwiler, S., 2010. Interspecific variation in leaf litter tannins drives decomposition in a tropical rain forest of French Guiana. Ecology 91, 2080-2091.

Corbeels, M., O'Connell, A.M., Grove, T.S., Mendham, D.S., Rance, S.J., 2003. Nitrogen release from eucalypt leaves and legume residues as influenced by their biochemical quality and degree of contact with soil. Plant Soil 250, 15-28.

Cornwell, W.K., Cornelissen, J.H.C., Amatangelo, K., Dorrepaal, E., Eviner, V.T., Godoy O., Hobbie, S.E., Hoorens, B., Kurokawa, H., Pérez-Harguindeguy, N., Quested, H. M., Santiago, L.S., Wardle, D.A., Wright, I.J., Aerts, R., Allison, S.D., van Bodegom, P., Brovkin, V., Chatain, A., Callaghan, T.V., Diaz, S., Garnier, E., Gurvich, D.E., Kazakou, E., Klein, J.A., Read, J., Reich, P.B., Soudzilovskaia, N.A., Vaieretti, V., Westoby, M., 2008. Plant species traits are the predominant control on litter decomposition rates within biomes worldwide. Ecol. Lett. 11, 1065-1071.

Craine, J.M., Morrow, C., Fierer, N., 2007. Microbial nitrogen limitation increases decomposition. Ecology 88, 2105-2113.

D’Annunzio, R., Zeller, B., Nicolas, M., Dhôte, J.F., Saint-André, L., 2008. Decomposition of European beech (Fagus sylvatica) litter: combining quality theory and ${ }^{15} \mathrm{~N}$ labelling experiments. Soil Biol. Biochem. 40, 322-333.

Enriquez, S., Duarte, C.M., Sand-Jensen, K., 1993. Patterns in decomposition rates among photosynthetic organisms: the importance of detritus C:N:P content. Oecologia 94, 457-471.

FAO, 2010. Global Forest Resources Assessment. <http://www.fao.org/forestry/fra/ fra2010/en/>.

Forrester, D.I., Bauhus, J., Cowie, A.L., Vanclay, J.K., 2006. Mixed-species plantations of Eucalyptus with nitrogen-fixing trees: a review. For. Ecol. Manage. 233, 211 230.

Forrester, D.I., Pares, A., O’Hara, C., Khanna, P.K., Bauhus, J., 2013. Soil organic carbon is increased in mixed-species plantations of Eucalyptus and nitrogen-fixing Acacia. Ecosystems 16, 123-132.

Forrester, D.I., 2014. The spatial and temporal dynamics of species interactions in mixed-species forests: from pattern to process. For. Ecol. Manage. 312, 282 292.

Freschet, G.T., Aerts, R., Cornelissen, J.H.C., 2012a. A plant economics spectrum of litter decomposability. Funct. Ecol. 26, 56-65.

Freschet, G.T., Aerts, R., Cornelissen, J.H.C., 2012b. Multiple mechanisms for trait effects on litter decomposition: moving beyond home-field advantage with a new hypothesis. J. Ecol. 100, 619-630.

Freschet, G.T., Cornwell, W.K., Wardle, D.A., Elumeeva, T.G., Liu, W., Jackson, B.G. Onipchenko, V.G., Soudzilovskaia, N.A., Tao, J., Cornelissen, J.H.C., 2013. Linking litter decomposition of above- and below-ground organs to plant-soil feedbacks worldwide. J. Ecol. 101, 943-952.

Gilmour, A.R., Gogel, B.J., Cullis, B.R., Welham, S.J., Thompson, R., 2005. ASReml User Guide Release 2.0. VSN International Ltd, Hemel Hempstead HP1 1ES.

Gholz, H.L., Wedin, D.A., Smitherman, S.M., Harmon, M.E., Parton, W.J., 2000. Longterm dynamics of pine and hardwood litter in contrasting environments: toward a global model of decomposition. Glob. Change Biol. 6, 751-765.

Gödde, M., David, M.B., Christ, M.J., Kaupenjohann, M., Vance, G.F., 1996. Carbon mobilization from the forest floor under red spruce in the northeastern USA. Soil Biol. Biochem. 28, 1181-1189.

Güsewell, S., Freeman, C., 2005. Nutrient limitation and enzyme activities during litter decomposition of nine wetland species in relation to litter $\mathrm{N}: \mathrm{P}$ ratios. Funct. Ecol. 19, 582-593.

Güsewell, S., Verhoeven, J.T.A., 2006. Nutrition limitation of leaf litter decomposability in wetland graminoids. Plant Soil 287, 131-143.

Güsewell, S., Gessner, M.O., 2009. N:P influence litter decomposition and colonization by fungi and bacteria in microcosms. Funct. Ecol. 23, 211-219.

Harwood, C.E., Nambiar, E.K.S., 2014. Productivity of acacia and eucalypt plantations in southeast Asia. 2. Trends and variations. Int. For. Rev. 16, 249-260.

Hättenschwiler, S., Bracht Jørgensen, H., 2010. Carbon quality rather than stoichiometry controls litter decomposition in a tropical rain forest. J. Ecol 98, 754-763.

Hättenschwiler, S., Coq, S., Barantal, S., Handa, I.T., 2011. Leaf traits and decomposition in tropical rainforests: revisiting some commonly held views and towards a new hypothesis. New Phytol. 189, 950-965.

Hessen, D.O., Ågren, G.I., Anderson, T.R., Elser, J.J., De Ruiter, P.C., 2004. Carbon sequestration in ecosystems: the role of stoichiometry. Ecology 85, 11791192.

Hobbie, S.E., 2000. Interactions between litter lignin and soil nitrogen availability during leaf litter decomposition in a Hawaiian Montane Forest. Ecosystems 3 484-494.

Hobbie, S.E., Oleksyn, J., Eissenstat, D.M., Reich, P.B., 2010. Fine root decomposition rates do not mirror those of leaf litter among temperate tree species. Oecologia $162,505-513$.

Hobbie, S.E., Eddy, W.C., Buyarski, C.R., Adair, E.C., Ogdahl, M.L., Weisenhorn, P., 2012. Response of decomposing litter and its microbial community to multiple forms of nitrogen enrichment. Ecol. Monogr. 82, 389-405.

Jensen, L.S., Salo, T., Palmason, F., Breland, T.A., Henriksen, T.M., Stenberg, B., Pedersen, A., Lundström, C., Esala, M., 2005. Influence of biochemical quality on $\mathrm{C}$ and $\mathrm{N}$ mineralisation from a broad variety of plant materials in soil. Plant Soil 273, 307-326.

Joanisse, G.D., Bradley, R.L., Preston, C.M., Munson, A.D., 2007. Soil enzyme inhibition by condensed litter tannins may drive ecosystem structure and processes: the case of Kalmia angustifolia. New Phytol. 175, 535-546.

Kaiser, C., Franklin, O., Dieckmann, U., Richter, A., 2014. Microbial community dynamics alleviate stoichiometric constraints during litter decay. Ecol. Lett. 17 680-690. 
Koutika, L.S., Epron, D., Bouillet, J.P., Mareschal, L., 2014. Changes in N and C concentrations, soil acidity and $\mathrm{P}$ availability in tropical mixed acacia and eucalypt plantations on a nutrient-poor sandy soil. Plant Soil 379, 205-216.

Laclau, J.P., Levillain, J., Deleporte, P., Nzila, J., Bouillet, J.P., Saint-André, L., Versini, A., Mareschal, L., Nouvellon, Y., Thongo M’Bou, A., Ranger, J., 2010. Organic residue mass at planting is an excellent predictor of tree growth in Eucalyptus plantations established on a sandy tropical soil. For. Ecol. Manage. 260, 2148 2159.

Makkar, H.P.S., Blümmel, M., Borowy, N.K., Becker, K., 1993. Gravimetric determination of tannins and their correlations with chemical and protein precipitation methods. J. Sci. Food Agric. 61, 161-165.

Makkonen, M., Berg, M.P., Handa, I.T., Hättenschwiler, S., van Ruijven, J., van Bodegom, P.M., Aerts, R., 2012. Highly consistent effects of plant litter identity and functional traits on decomposition across a latitudinal gradient. Ecol. Lett. $15,1033-1041$

Manzoni, S., Trofymow, J.A., Jackson, R.B., Porporato, A., 2010. Stoichiometric controls on carbon, nitrogen, and phosphorus dynamics in decomposing litter. Ecol. Monogr. 80, 89-106.

Melillo, J.M., Aber, J.D., Muratore, J.F., 1982. Nitrogen and lignin control of hardwood leaf litter decomposition dynamics. Ecology 63, 621-626.

Melillo, J.M., Aber, J.D., Linkins, A.E., Ricca, A., Fry, B., Nadelhffer, K.J., 1989. Carbon and nitrogen dynamics along the decay continuum: Plant litter to soil organic matter. Ecology of Arable land - perspectives and challenges. Develop. Plant Soil Sci. 39, 53-62.

Mello, S.L.M., Goncalves, J.L.M., Gava, J.L., 2007. Pre- and post-harvest fine root growth in Eucalyptus grandis stands installed in sandy and loamy soils. For. Ecol. Manage. 246, 186-195

Mendham, D.S., Ogden, G.N., Short, T., O’Connell, T.M., Grove, T.S., Rance, S.J., 2014 Repeated harvest residue removal reduces E. globulus productivity in the 3rd rotation in south-western Australia. For. Ecol. Manage. 329, 279-286.

Michel, K., Matzner, E., 2002. Nitrogen content of forest floor Oa layers affects carbon pathways and nitrogen mineralization. Soil Biol. Biochem. 34, 18071813.

Moorhead, D.L., Lashermes, G., Sinsabaugh, R.L., Weintraub, M.N., 2013. Calculating co-metabolic costs of lignin decay and their impacts on carbon use efficiency. Soil Biol. Biochem. 66, 17-19.

Mooshammer, M., Wanek, W., Schnecker, R.G., Wild, B., Leitner, S., Hofhansl, F., Blöch, A., Hämmerle, I., Frank, A.H., Fuchslueger, L., Keiblinger, M., Zechmeister-Boltenstern, S., Richter, A., 2012. Stoichiometric controls of nitrogen and phosphorus cycling in decomposing beech leaf litter. Ecology 93, 770-782.

Nambiar, E.K.S., Harwood, C.E., 2014. Productivity of acacia and eucalypt plantations in southeast Asia. 1. Bio-physical determinants of production: opportunities and challenges. Int. For. Rev. 16, 225-248.

Northup, R.R., Yu, Z., Dahlgren, R.A., Vogt, K.A., 1995. Polyphenol control of nitrogen release from pine litter. Nature 377, 227-229.

Nouvellon, Y., Laclau, J.P., Epron, D., le Maire, G., Bonnefond, J.M., Gonçalves, J.L.M., Bouillet, J.P., 2012. Production and carbon allocation in monocultures and mixed-species plantations of Eucalyptus grandis and Acacia mangium in Brazil. Tree Physiol. 32, 680-695.
Osanai, Y., Flittner, A., Janes, J.K., Theobald, P., Pendall, E., Newton, P.C.D., Hovenden, M.J., 2012. Decomposition and nitrogen transformation rates in a temperate grassland vary among co-occurring plant species. Plant Soil 350, 365-378.

Ostertag, R., Hobbie, S.E., 1999. Early stages of root and leaf decomposition in Hawaiian forests: effects of nutrient availability. Oecologia 121, 564-573.

Rachid, C.T.C.C., Balieiro, F.C., Peixoto, R.S., Pinheiro, Y.A.S., Piccolo, M.C., Chaer, G.M., Rosado, A.S., 2013. Mixed plantations can promote microbial integration and soil nitrate increases with changes in the N cycling genes. Soil Biol. Biochem. 66, 146-153.

Rachid, C.T.C.C., Balieiro, F.C., Fonseca, E.S., Peixoto, R.S., Chaer, G.M., Tiedje, J.M., Rosado, A.S., 2015. Intercropped silviculture systems, a key to achieving soil fungal community management in eucalyptus plantations. PLoS ONE, 10.

Ribeiro, C., Madeira, M., Araújo, M.C., 2002. Decomposition and nutrient release from leaf litter of Eucalyptus globulus grown under different water and nutrient regimes. For. Ecol. Manage. 171, 31-41.

Silver, W.L., Miya, R.K., 2001. Global patterns in root decomposition: comparisons of climate and litter quality effects. Oecologia 129, 407-419.

Strickland, M.S., Lauber, C., Fierer, N., Bradford, M.A., 2009. Testing the functional significance of microbial community composition. Ecology 90, 441-451.

Sun, T., Mao, Z., Han, Y., 2013. Slow decomposition of very fine roots and some factors controlling the process: a 4-year experiment in four temperate tree species. Plant Soil 372, 445-458.

Uselman, S.M., Qualls, R.G., Lilienfein, J., 2012. Quality of soluble organic C, N, and P produced by different types and species of litter: root litter versus leaf litter. Soil Biol. Biochem. 54, 57-67.

Van Soest, P.J., 1964. New chemical procedures for evaluating forages. J. Anim. Sci. 23, 838-845.

Veen, G.F., Freschet, G.T., Ordonez, A., Wardle, D.A., 2015. Litter quality and environmental controls of home-field advantage effects on litter decomposition. Oikos 124, 187-195.

Vivanco, L., Austin, A.T., 2006. Intrinsic effects of species on leaf litter and root decomposition: a comparison of temperate grasses from North and South America. Oecologia 150, 97-107.

Vivanco, L., Austin, A.T., 2008. Tree species identity alters forest litter decomposition through long-term plant and soil interactions in Patagonia, Argentina. J. Ecol. 96, 727-736.

Voigtlaender, M., Laclau, J.P., Gonçalves, J.L.M., de Cássia Piccolo, M., Moreira, M.Z., Nouvellon, Y., Ranger, J., Bouillet, J.P., 2012. Introducing Acacia mangium trees in Eucalyptus grandis plantations: consequences on soil organic matter stocks and nitrogen mineralization. Plant Soil 352, 99-111.

Xiang, W., Bauhus, J., 2007. Does the addition of litter from N-fixing Acacia mearnsii accelerate leaf decomposition of Eucalyptus globulus? Austral. J. Bot. 55, 576583.

Wang, Q., Zhong, M., Tongxin, H., 2013. Home-field advantage of litter decomposition and nitrogen release in forest ecosystems. Biol. Fertil. Soils 49, 427-434.

Wickings, K., Grandy, A.S., Reed, S.C., Cleveland, C.C., 2012. The origin of litter chemical complexity during decomposition. Ecol. Lett. 15, 1180-1188.

Wu, F., Peng, C., Yang, W., Zhang, J., Han, Y., Mao, T., 2014. Admixture of alder (Alnus formosana) litter can improve the decomposition of eucalyptus (Eucalyptus grandis) litter. Soil Biol. Biochem. 73, 115-121. 